\title{
Assessment of Go-Jek Transfortation Services in Indonesia Through Gap Service Quality and Impact on Consumer Loyalty
}

\author{
Eko Wijaya ${ }^{1)}$, Dayal Gustopo Setiadjit ${ }^{2)}$, Nelly Budiharti ${ }^{3)}$ \\ ${ }^{1}$ Student, Post-graduate Department of Industrial Engineering ITN Malang \\ ${ }^{2}$ Lecturers, Post-graduate Department of Industrial Engineering ITN Malang \\ ${ }^{3}$ Lecturers, Post-graduate Department of Industrial Engineering ITN Malang \\ Malang, Indonesia
}

\begin{abstract}
Along with the development of transportation era, it becomes a very important need in running the wheels of the people's economy, with the increase in online-based technology, competition in the field of online transportation can not be avoided. To be able to compete with other online transportation companies by improving the quality of services provided to consumers. The purpose of this study is to evaluate the quality of service of PT. Go-Jek Indonesia for consumers. Based on the results of this study using the Service Quality method (seen from Tangible, Reliability, Responsiveness, Assuransc, Emphaty ) by distributing questionnaires using Google forms to 400 respondents throughout the service area of PT. Go-Jek Indonesia. The results of the service quality / gap calculation for each statement dimension are all of negative values, indicating that the services provided by PT. Go-Jek Indonesia cannot be said of quality or service quality does not meet the expectations of Go-Jek customers. This condition shows that there is still a need to improve the quality of services provided by PT. GoJek Indonesia in order to achieve the ideal service quality to remain competitive with other competitors.
\end{abstract}

Keywords:- Online Transparency, Service Quality, Service Quality.

\section{INTRODUCTION}

Transportation has a very important role in the economic life of the community. Transportation is the movement of people or goods from one place to another by using a vehicle that is driven by machines or people. Transportation is used to facilitate humans in their daily economic activities. Very rapid progress in the field of information technology has a major influence on various aspects of human life. The most obvious effect is seen in the fundamental changes in the way people conduct transactions, especially in the business world. One result of the progress of information technology that has contributed greatly to these changes is the internet. The internet is a network that is connected with communication tools so that they can interact anytime, anywhere. The development of the internet can change companies in conducting transactions, from the old way that the process of sacrificing time and costs is large into a faster and easier process.

In 2010, a startup company by the nation's son was established as the first platform in Indonesia called PT. GoJek Indonesia, which is engaged in providing information on public transportation services (two-wheeled and fourwheeled transportation) was established by Nadiem Karim and Michaelangelo Moran . Go-Jek Company as an intermediary connects motorcycle taxi riders with customers. C ompany Go -J oak application launches mobile Go -J ek-based location-based search that can be accessed by mobile users based on Android or iOS (Apple) in January 2015. Through the application of Go-Jek , the driver can see the orders were coming from customers and pick-up location, while customers can monitor the position of the driver $\mathrm{g}$ motorcycle taxis, which accept orders .

The rapid growth of the transportation industry, both the service industry and the manufacturing industry, raises competition and demands companies to further increase operational activities in order to improve quality to win the competition [1]. Given that it is so important a service in the field of services that will affect the quantity of service to customers so that the business can continue to run. Assessment of service quality is very important so that it can help businesses in efforts to improve the quality of better services in the future. Satisfaction is a feeling of pleasure or disappointment that results from a comparison of product performance against customer expectations [2] . 
ISSN No:-2456-2165

\begin{tabular}{|c|c|c|c|}
\hline No & Item & Service Standards & Actual Services \\
\hline 1 & Pickup time & $\begin{array}{l}\text { Five minutes to the customer ( } g o-\text { ride } \\
\text { service) }\end{array}$ & More than five minutes \\
\hline 2 & Driver appearance & $\begin{array}{l}\text { Using an official Go-Jek jacket, neat, } \\
\text { clean. }\end{array}$ & $\begin{array}{l}\text { Sometimes it doesn't use the Go-Jek attribute, } \\
\text { it's not neat and looks dirty }\end{array}$ \\
\hline 3 & Vehicle condition & $\begin{array}{l}\text { Worth the road in accordance with } \\
\text { factory standards and traffic regulations }\end{array}$ & $\begin{array}{l}\text { Sometimes vehicles do not meet factory } \\
\text { standards }\end{array}$ \\
\hline 4 & Traffic rules & Obey in traffic & $\begin{array}{l}\text { Sometimes it breaks the red light and stops out of } \\
\text { place }\end{array}$ \\
\hline 5 & $\begin{array}{l}\text { Completeness when } \\
\text { getting an order }\end{array}$ & $\begin{array}{l}\text { Bring a helmet, mask, head cover, } \\
\text { raincoat. }\end{array}$ & $\begin{array}{l}\text { Do not give or offer masks, headgear, and often } \\
\text { reason not to bring a raincoat to refuse orders }\end{array}$ \\
\hline
\end{tabular}

Table 1:- Quality of service go-jek (GAP)

(Source: Personal data of interview results, 2019)

Based on table 1, we need facts that become the basis for the research to choose the Service Quality ( servqual) method, namely to know GAP the level of service quality provided by the object to the customer and dimensions, which attributes will be a priority to maintain or improve the quality of service provided by the Go- Indonesian jek . In this study aims to evaluate the quality of service of PT . Go-Jek Indonesia for customers is seen from the five dimensions of Service Quality .

\section{RESEARCH METHODOLOGY}

\section{A. Types of research}

This type of research uses quantitative methods. Quantitative research is an empirical study in which data is in the form of numbers [3]. Quantitative Method is a research methodology based on the philosophy of positivism, used to examine specific populations or samples and to test hypotheses that have been determined by using ordinal data types. Frameworks s eperti in Figure 1 below:

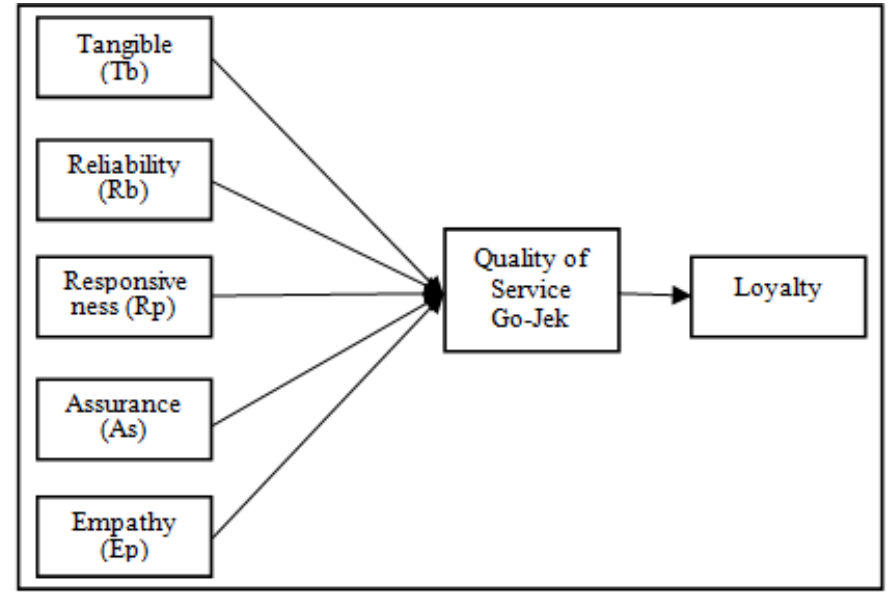

Fig 1:- Framework for Thinking

\section{RESEARCH RESULT}

\section{A. Presentation of Results Data}

Test Instruments (Validity and Reliability)

Test the Validity of Perception Research Instruments for Servqual

\begin{tabular}{|c|c|c|c|c|c|}
\hline \multirow[b]{2}{*}{ Variable } & \multirow[b]{2}{*}{ Item } & \multicolumn{3}{|c|}{ Validity test } & \multirow[b]{2}{*}{ Decision } \\
\hline & & $\begin{array}{c}\text { Correlation } \\
(\boldsymbol{r})\end{array}$ & r table & Sign. $(P)$ & \\
\hline \multirow{3}{*}{ Tangible } & Tangible & 0.728 & 0.098 & 0,000 & Valid \\
\hline & Tangible. 2 & 0.812 & 0.098 & 0,000 & Valid \\
\hline & Tangible. 3 & 0.892 & 0.098 & 0,000 & Valid \\
\hline \multirow{3}{*}{ Reliability } & Reliability & 0.722 & 0.098 & 0,000 & Valid \\
\hline & Reliability. 2 & 0.866 & 0.098 & 0,000 & Valid \\
\hline & Reliability.3 & 0.787 & 0.098 & 0,000 & Valid \\
\hline \multirow{2}{*}{ Responsivenes } & Responsivenes. 1 & 0.89 & 0.098 & 0,000 & Valid \\
\hline & Responsivenes.2 & 0.873 & 0.098 & 0,000 & Valid \\
\hline \multirow{3}{*}{ Assurance } & Assurance.1 & 0.842 & 0.098 & 0,000 & Valid \\
\hline & Assurance. 2 & 0.871 & 0.098 & 0,000 & Valid \\
\hline & Assurance. 3 & 0.887 & 0.098 & 0,000 & Valid \\
\hline Empathy & Empathy & 0.673 & 0.098 & 0,000 & Valid \\
\hline
\end{tabular}


ISSN No:-2456-2165

\begin{tabular}{|c|c|c|c|c|c|}
\multirow{5}{*}{} & Empathy.2 & 0.766 & 0.098 & 0,000 & Valid \\
\cline { 2 - 5 } & Empathy.3 & 0.739 & 0.098 & 0,000 & Valid \\
\cline { 2 - 5 } & Empathy.4 & 0837 & 0.098 & 0,000 & Valid \\
\cline { 2 - 6 } & Empathy.5 & 0.787 & 0.098 & 0,000 & Valid \\
\hline \multirow{3}{*}{ Satisfaction } & Satisfaction.1 & 0.823 & 0.098 & 0,000 & Valid \\
\cline { 2 - 6 } & Satisfaction.2 & 0.833 & 0.098 & 0,000 & Valid \\
\cline { 2 - 6 } & Satisfaction.3 & 0.856 & 0.098 & 0,000 & Valid \\
\hline \multirow{3}{*}{ Loyalty } & Loyalty.1 & 0.699 & 0.098 & 0,000 & Valid \\
\cline { 2 - 6 } & Loyalty.2 & 0.765 & 0.098 & 0,000 & Valid \\
\cline { 2 - 6 } & Loyalty.3 & 0.854 & 0.098 & 0,000 & Valid \\
\hline
\end{tabular}

Table 2

(Source: appendix to the results of an analysis of the instrument validity test)

Research Instrument Reliability Test

\begin{tabular}{|c|c|c|}
\hline Variable & Alpha Cronbach & Information \\
\hline Tangible & 0.708 & High level of reliability \\
\hline Reliability & 0.701 & High level of reliability \\
\hline Responsivenes & 0.697 & High level of reliability \\
\hline Assurance & 0.837 & The level of reliability is very high \\
\hline Empathy & 0.811 & The level of reliability is very high \\
\hline Satisfaction & 0.787 & High level of reliability \\
\hline Loyalty & 0.633 & High level of reliability \\
\hline
\end{tabular}

Table 3

(Source: appendix results of the instrument reliability test analysis)

Test Validity of Research Instruments Expectations for Servqual

\begin{tabular}{|c|c|c|c|c|c|}
\hline \multirow{2}{*}{ Variable } & \multirow[b]{2}{*}{ Item } & \multicolumn{3}{|c|}{ Validity test } & \multirow[b]{2}{*}{ Decision } \\
\hline & & $\begin{array}{c}\text { Correlation } \\
(r)\end{array}$ & r table & Sign. $(P)$ & \\
\hline \multirow{3}{*}{ Tangible } & Tangible & 0.800 & 0.098 & 0,000 & Valid \\
\hline & Tangible. 2 & 0.857 & 0.098 & 0,000 & Valid \\
\hline & Tangible. 3 & 0.836 & 0.098 & 0,000 & Valid \\
\hline \multirow{3}{*}{ Reliability } & Reliability & 0.887 & 0.098 & 0,000 & Valid \\
\hline & Reliability. 2 & 0.874 & 0.098 & 0,000 & Valid \\
\hline & Reliability.3 & 0.904 & 0.098 & 0,000 & Valid \\
\hline \multirow{2}{*}{ Responsivenes } & Responsivenes & 0.943 & 0.098 & 0,000 & Valid \\
\hline & Responsivenes. 2 & 0.936 & 0.098 & 0,000 & Valid \\
\hline \multirow{3}{*}{ Assurance } & Assurance.1 & 0.888 & 0.098 & 0,000 & Valid \\
\hline & Assurance. 2 & 0.89 & 0.098 & 0,000 & Valid \\
\hline & Assurance. 3 & 0.887 & 0.098 & 0,000 & Valid \\
\hline \multirow{5}{*}{ Empathy } & Empathy & 0.802 & 0.098 & 0,000 & Valid \\
\hline & Empathy. 2 & 0.822 & 0.098 & 0,000 & Valid \\
\hline & Empathy.3 & 0.735 & 0.098 & 0,000 & Valid \\
\hline & Empathy.4 & 0.841 & 0.098 & 0,000 & Valid \\
\hline & Empathy.5 & 0.819 & 0.098 & 0,000 & Valid \\
\hline
\end{tabular}

Table 4

(Source: attachment of the results of the analysis of the validity of the instrument) 
Research Instrument Reliability Test

\begin{tabular}{|c|c|c|}
\hline Variable & Alpha Cronbach & Information \\
\hline Tangible & 0743 & High level of reliability \\
\hline Reliability & 0.860 & The level of reliability is very high \\
\hline Responsivenes & 0866 & The level of reliability is very high \\
\hline Assurance & 0.859 & The level of reliability is very high \\
\hline Empathy & 0.860 & The level of reliability is very high \\
\hline
\end{tabular}

Table 5

(Source: appendix results of the instrument reliability test analysis)

\section{Servic Quality Test Value Calculation}

Servqual value is obtained from the calculation of the perception questionnaire and the results of the expectation questionnaire and then the results of the value are processed by means of the perception value reduced by the expectation produced by the servqual value.

$$
\mathbf{Q}=\mathbf{P}-\mathbf{E}
$$

Information :

$\mathrm{Q}=$ Customer satisfaction

$\mathrm{P}=$ customer perception

$\mathrm{E}=$ customer expectations [4] .

If:

Expectations> Perception : Not Qualified

Expectation $=$ Perception : Quality

Expectations < Perception : Very high quality

The following is the result data from servqual value calculation :

\begin{tabular}{|c|c|c|c|c|}
\hline Dimensions $(n=400)$ & Perception & Expectations & $\begin{array}{c}\text { Service } \\
\text { Quality (Gap) }\end{array}$ & Information \\
\hline \multicolumn{5}{|c|}{$\begin{array}{ll}\text { Tangibles (Real Evidence) } \\
\end{array}$} \\
\hline $\begin{array}{l}\text { GO-JEK uses good vehicles. Provides information } \\
\text { about the products being sold }\end{array}$ & 4.22 & 4.25 & -0.02 & Not qualified \\
\hline $\begin{array}{l}\text { GO-JEK complements vehicle attributes according to } \\
\text { the Indonesian National Police standards. }\end{array}$ & 4.29 & 4.30 & -0.01 & Not qualified \\
\hline $\begin{array}{l}\text { GO-JEK gives customers additional attributes for } \\
\text { driving such as masks or raincoats. }\end{array}$ & 3.54 & 3.91 & -0.37 & Not qualified \\
\hline Total & 12.06 & 12.46 & $-\mathbf{0 , 4 0}$ & \\
\hline Average & 4.02 & 4.15 & $-\mathbf{0 , 1 3}$ & Not qualified \\
\hline \multicolumn{5}{|c|}{ Reliability (Reliability) } \\
\hline $\begin{array}{l}\text { GO-Jek Deliver customers or orders precisely } \\
\text { according to the order }\end{array}$ & 4.24 & 4.25 & -0.01 & Not qualified \\
\hline $\begin{array}{l}\text { The network system used by GO-JEK for ordering is } \\
\text { very fast and accurate }\end{array}$ & 4.01 & 4.13 & -0.12 & Not qualified \\
\hline Services provided by the driver can be trusted. & 4.18 & 4.22 & -0.04 & Not qualified \\
\hline Total & 12.45 & 12.61 & -0.17 & \\
\hline Average & 4.15 & 4.20 & -0.06 & Not qualified \\
\hline \multicolumn{5}{|c|}{ Responsiveness (Responsiveness) } \\
\hline $\begin{array}{c}\text { GO-JEK provides solutions if problems occur when } \\
\text { customers order }\end{array}$ & 4.06 & 4.14 & -0.08 & Not qualified \\
\hline GO-JEK picks up and delivers customers on time & 4.04 & 4.16 & -0.12 & Not qualified \\
\hline Total & 8,11 & 8.31 & -0.25 & \\
\hline Average & 4.06 & 4.16 & -0.08 & Not qualified \\
\hline \multicolumn{5}{|c|}{ Assurance (Assurance) } \\
\hline $\begin{array}{l}\text { GO-JEK drivers behave politely when serving } \\
\text { customers }\end{array}$ & 4.23 & 4.24 & -0.01 & Not qualified \\
\hline GO-JEK can be trusted to provide services & 4.14 & 4.18 & -0.04 & Not qualified \\
\hline GO-JEK prioritizes customer safety. & 4.13 & 4.27 & $-0,14$ & Not qualified \\
\hline Total & 12.51 & $\mathbf{1 2 , 7 0}$ & -0.19 & \\
\hline Average & 4.17 & 4.23 & -0.06 & Not qualified \\
\hline \multicolumn{5}{|c|}{ Emphaty (Empathy) } \\
\hline $\begin{array}{l}\text { GO-JEK is a transportation business that prioritizes } \\
\text { customer safety }\end{array}$ & 4.04 & 4.15 & -0.12 & Not qualified \\
\hline Drivers say greetings opening (good morning / & 3.82 & 4.03 & -0.21 & Not qualified \\
\hline
\end{tabular}


ISSN No:-2456-2165

\begin{tabular}{|c|c|c|c|c|}
\hline afternoon / evening) at the beginning of service & & & & \\
\hline Drivers care about customer desires & 3.96 & 4.18 & -0.23 & Not qualified \\
\hline $\begin{array}{c}\text { PT. GO-JEK Indonesia is gathering for customers to } \\
\text { establish good relations between customers and drivers }\end{array}$ & 3.61 & 4.04 & -0.43 & Not qualified \\
\hline GO-JEK gives individual attention to customers & 3.64 & 3.90 & -0.27 & Not qualified \\
\hline Total & $\mathbf{1 9 . 0 8}$ & $\mathbf{2 0 . 3 3}$ & $\mathbf{- 0 . 9 2}$ & Not qualified \\
\hline Average & $\mathbf{3 . 8 2}$ & $\mathbf{4 . 0 7}$ & $\mathbf{- 0 . 3 1}$ &
\end{tabular}

Table 6:- Calculation of the Servqual value

(Source: Data Processing)

From table 2 the calculation of servqual values shows the servqual value of a negative value, obtained from the results of the perception value reduced by expectations. Negative servqual value, which means that service at Go-Jek Company has not met customer expectations (expectations) for the desired service quality.

\begin{tabular}{|c|c|c|c|c|}
\hline Dimension & $\begin{array}{c}\text { Average perception } \\
\text { value }\end{array}$ & $\begin{array}{c}\text { Average expectation } \\
\text { value }\end{array}$ & The gap & Information \\
\hline Tangibles ( living proof) & 4.02 & 4.15 & $-0,13$ & Not qualified \\
\hline Reliability (Reliability) & 4.15 & 4.20 & -0.05 & Not qualified \\
\hline $\begin{array}{c}\text { Responsiveness } \\
\text { Responsiveness) }\end{array}$ & 4.06 & 4.15 & -0.09 & Not qualified \\
\hline Assurance (Assurance) & 4.17 & 4.23 & -0.06 & Not qualified \\
\hline Emphaty (Empathy) & 3.82 & 4.07 & -0.25 & Not qualified \\
\hline
\end{tabular}

Table 7:- Results of Go-Jek customer Gap analysis

(Source: Data Processing)

\section{CONCLUSION}

Overall, the results of the calculation of service quality / gap for each statement dimension are all negative, indicating that the services provided by PT. Go-Jek Indonesia cannot be said of quality or service quality does not meet the expectations of Go-Jek customers. This condition shows that there is still a need to improve the quality of services provided by PT. Go-Jek Indonesia in order to achieve the ideal service quality to remain competitive with other competitors.

\section{REFERENCES}

[1]. Ali Hasan, Marketing and Selected Cases, (Cups Publishing, 2013) h. 94.

[2]. Kotler and Keller. 2012. Marketing Management . Volume I. 13th Edition Jakarta: Erlangga.

[3]. Syahrum and Salim, Quantitative Research Methodology , (Citapustaka Media, Bandung: 2012), p.39

[4]. Parasuraman, A., Berry, Leonard L, and Zeithaml, Valarie A. 1985. "A Conceptual Model of Service Quality and Its Implications for Future Research". Journal of Marketing, Vol; 49 (Fall), pp. 41-50. 